\title{
The Strategic Integration of Enterprises as Determinant of Merger and Acquisition Success
}

\author{
Dushica Stevchevska Srbinoska \\ University American College Skopje, Macedonia \\ E-mail: dusica1@yahoo.com
}

Received: July 13, 2016 Accepted: October 28, 2016 Published: November 22, 2016

doi:10.5296/ijafr.v6i2.9739 URL: http://dx.doi.org/10.5296/ijafr.v6i2. 9739

\begin{abstract}
Mergers and acquisitions are driven by the same motive: synergy creation and realization of larger value by combining companies. However, numerous merger and acquisition efforts show a lack of critical success elements: attention directed towards integration of employees and work processes. In this research, I focus on analysis of the meaning of post-transactional integration of mergers and acquisitions as a determinant to the business deal success, with particular emphasis on the Republic of Macedonia. The success of the merger i.e. acquisition act depends on how the deal is conducted, i.e. on the success of the integration process, which I demonstrate through a field research across several Macedonian enterprises.
\end{abstract}

Keywords: Merger and acquisition, Integration process, Macedonian market 


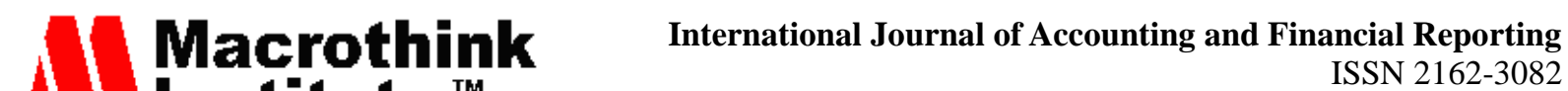 2016, Vol. 6, No. 2}

\section{Introduction}

Mergers and acquisitions are driven by the same motive: synergy creation and realization of larger value by combining companies. However, numerous merger and acquisition efforts show a lack of critical success elements: attention directed towards integration of the employees and the work processes. In this research, I focus on analysis of the meaning of the post-transactional integration of mergers and acquisitions as a determinant to the business deal success, with particular emphasis on the Republic of Macedonia. The success of the merger i.e. acquisition act depends on how the deal is conducted, i.e. on the success of the integration process, which I demonstrate through a field research across several Macedonian industries. The field research encompasses 10 large and well-known enterprises that were or are part of some integration process as a result of merger/acquisition transaction. The research demonstrates that the post-merger integration success is highly dependent on the communication across all organization levels as well as on the efficient integration of the human resources and their enhancement. The conclusion to the theoretical as well as practical research shows that only well-organized merger and acquisition integrations achieve the final goal: ameliorating the operations of the merging companies and maximizing synergy potentials. These gains are as well transferred to the owners through increase of long-term profit per share.

\section{Merger and Acquisition Stages}

Although every strategic plan is thoroughlly revised in order to 'do the right thing', the plan should be well implemented, i.e. 'done in the right manner'. Traditionally, integration gets implemented after conducting the deal. Nonetheless, this approach normally leads to postponing and frictioning which often reduces the transaction benefits. It is by far more effcicient to initiate the integration process in the early transaction stages and to insist on disciplined implementation, as indicated by companies that have been through multiple successful mergers and acquisitons.

The acquisition process consists of three preliminary stages that are subdivided into numerous substages, as presented in Table 1:

Table 1. Merger and acquisiton stages

\begin{tabular}{|l|l|l|}
\hline Strategy & Sub-stages & Goals of the stage \\
\hline $\begin{array}{l}\text {-Planning } \\
\text {-Valuation } \\
\text {-Selection }\end{array}$ & $\begin{array}{l}\text { - Several-fold increase of the worth, such as short- } \\
\text { term revenues, higher ROI, number of patents in } \\
\text { the portfolio, etc.) } \\
\text { - Value and capacity increase through weakness } \\
\text { elimination and strength fortification (reducing }\end{array}$ \\
\hline
\end{tabular}




\begin{tabular}{|c|c|c|}
\hline & & $\begin{array}{l}\text { competition through horizontal M\&A deals, } \\
\text { integrating supply chains through vertical delas, } \\
\text { diversifying the business through diagonal deals) }\end{array}$ \\
\hline Transaction & $\begin{array}{l}\text {-Due dilligence } \\
\text {-Financing } \\
\text {-Negotiating } \\
\text {-Structuring } \\
\text { (tax,legal and } \\
\text { accountging } \\
\text { treatment of the } \\
\text { transaction) } \\
\text {-Closing }\end{array}$ & $\begin{array}{l}\text { Detailed examination of the target entity: } \\
\text { - Risks - due dilligence } \\
\text { - Financing - sources of financing } \\
\text { - Adequate contracts and guarantees - negotiaion } \\
\text { - Ensuring the most favorable tax treatment for } \\
\text { both entities - tax substage } \\
\text { - Timely implementation of the deal - closing of } \\
\text { the transaction }\end{array}$ \\
\hline Integration & $\begin{array}{l}\text {-Integration planning } \\
\text {-Integration-related } \\
\text { communication } \\
\text { - Integration } \\
\text { implementation }\end{array}$ & $\begin{array}{l}\text { - Ensure support for the enitity's strategy through } \\
\text { integration } \\
\text { - Neutralize the risks that have emerged during the } \\
\text { transaction stage } \\
\text { - Ensure timeliness in order to minimize potential } \\
\text { costs } \\
\text { - Ensure open communication channels }\end{array}$ \\
\hline
\end{tabular}

Source: Manuel Sanches and Larry Dell, 2007.

The substages are initiated during the transaction phase and last until the end of integration. Every step should have precise targets, activity lists, input and output. The third stage is of particular interst for this research and will be analyzed in continuation.

\subsection{Phase 3: Integration}

The integration phase inputs and results can be structured as follows:

\subsubsection{Integration planning}

The aim of this substage is to plan all integration stages for the purpose of timely and costefficient realization of the strategic goals. This aim necessitates implementation of several crucial activities, such as: 


\section{Macrothink

- Plan preparation

- Evaluation of the environment

- Definition of the aims of the planning process

- Identification of resources - creating teams

- Verification of the plan (plan adoption).

The outcome of the integration planning process is the integration plan that enlists specific deadlines and goals.

\subsubsection{Integration communication}

The aim of this substage is to communicate the plans and results to the relevant people. In order to enable better communication, the integration leader must impose deadlines and communication channels such as minutes of meeting/memoranda.

\subsubsection{Integration implementation}

The aim of this substage is to integrate the two entities in a fast and effective fashion, as well as to realize the values that have been detected during the strategic phase according to the limitations and priorities identified during the transaction phase. The following activities enable the integration implementation:

- Creating teams

- Devising measurable goals

- Imposing deadlines

- Using resources to implement the plan

- Regular communication - documenting the communication

In order to conduct the integration, the integration leader(s) should prepare lists with core activities, main financials, intellectual, human and tangible assets, and cultural specifics. Furthermore, one should not ommit:

- Proposed deadlines and goals of the M\&A deal

- Organizational structures of the two entities

- Financial statements of the two entities

- Intellectual properties of the two entities

- Contracts and liabilities of the two entities

- Visions and missions

Upon completion of the integration process, the new entity can prepare output documents that can be used as basis for its future develoipment. These output documents must contain 


\section{Macrothink}

International Journal of Accounting and Financial Reporting

ISSN 2162-3082 2016, Vol. 6, No. 2

information on goals and deadlines, organizational structure of the new entity, financial statements, intellectual property, vision and mission of the newly combined company. In my view, every one of these substages is of vital meaning for the merger/acquisition process because these results and analyses can help devise the transaction course and the operational activities. Certainly, the acknowledgements can help design the legal approach that will be applied in the process of integration.

\section{Facilitating a Posteriori Integration}

Every merger or mutual investment needs to ensure fast implementation in order to reap the desired synergies. The employees, the clients, the regulatory bodies, the suppliers, the investors, the local communities, and the competitors are important factors with impact to the success of the merger and to the long-term performance of the new entity.

Creating an integration team that will support the integration efforts can accelerate the task completion and is of vital meaning for the synergy realization. Working in confidential manner, this team has unlimited access to the data of the two companies, information that is normally not made available to the other employees until deal completion. Upon arranging and analysing these data, the team can quickly deliver findings that will help decision-makers plan the structure and operations of the new company even before completing the M\&A deal.

Having this in mind, it is surprising to know that management do not often implement the practice of integration teams. Numerous managers share the opinion that there is not sufficient time for the integration team to achieve any results prior to implementing the M\&A transaction. Some are worried that sharing confidential information may expose their entities to unnecessary risk should the deal fail. Many times management underestimate the time needed to complete the transaction stage, which took approximately three months for most mergers in the USA in 2004. 


\section{MInstitute Macrink}

International Journal of Accounting and Financial Reporting

ISSN 2162-3082

Graph 1. Mergers and number of days from announcement until effective transaction completion

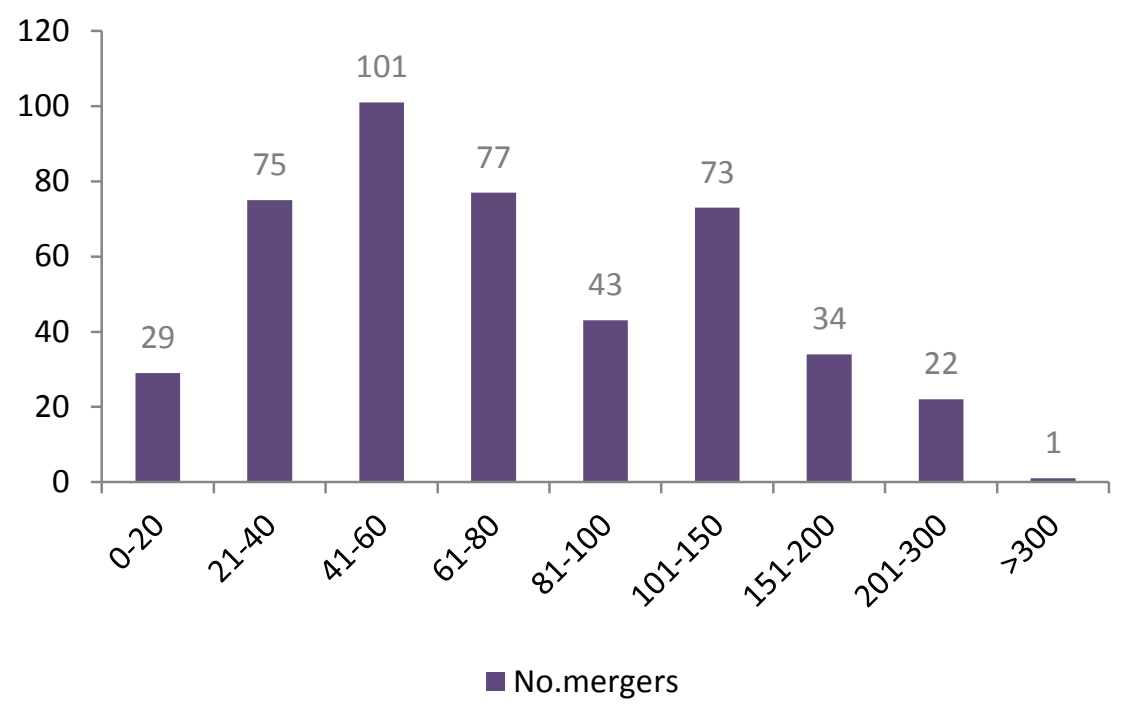

Source: Nicolas J. Albizzatti, Scott A. Christofferson, and Diane L. Sias, 2016.

Graph 1 depicts the duration of the 455 largest USA mergers announced in 2004. The average timeframe of three months leaves plenty of time not only for the integration team to conduct analyses and to make important decisions in regards to the post-deal integration, but also to prepare for the operational set-up of the new entity from the very beginning. Thus, the preparatory work of the team will help consume the synergy benefits before competitors decide to react or attack.

Integration teams: Integration teams can facilitate numerous pre-integration analyses and can help plan sensitive or legally limited data that would otherwise impede on future cooperation. In practice, the work of these teams can vary depending on the time limitations, availability of public information within the particular industry, as well as the previous relations between the two entities. The size and structure of these teams certainly depends on the time available for them to do their work in the field (Investor Words.com, 2006). Their primary task is to collect and harmonize data, which is preparatory work for the integration of the two businesses. Also, these preparations will help provide precise answers to the regulatory authorities regarding product and service divestitures. The team must first decide which information will be needed to conduct the M\&A deal. These information will vary in accordance with the synergies that should be delivered with the particular M\&A transaction. The team should be able to collect and harmonize data in a readable and comparable format. Finally, the team should be able to inform the decision makers regarding the meaning of data collected which will enable fast detection of problems and harmonizing information between the two entities. 


\section{Macrothink \\ International Journal of Accounting and Financial Reporting \\ ISSN 2162-3082 \\ 2016, Vol. 6, No. 2}

\section{Facilitating Human Resources Integration}

The replacement or retaining of employees in M\&A deals is partially dependant on the applied integration approach and on the similarities between the two companies. Deals within the same industry, such as consolidation of two commercial banks operating in the same geographic area, normally mean workforce surplus, especially amongst the sales network.

Management must balance the need to reduce workforce and the need to minimize the complexities employees face during the integration process. High turnover rates within acquired companies can have negative impact on the new entity's results due to loss of critical resources and tallents and demotivation of the remaining employees. This can seriously damage work ethics, employee loyalty, quality of service provided to clients and their retention, while having detrimental effect on potential synergies such as cross-selling.

Several steps are indispensable when it comes to efficient human resource management:

- Managment should identify key staff that must be retained in the new entity

- The selection process prior to determining surpluses, substitutes, or retention should be transparent and just. Ideally, the staff from both companies should be subjected to the same evaluation and selection process

- All staffing decisions must be made fast, within 100 days following the merger/acquisition announcement, in order to avoid all uncertainties, which may fully erode the work ethics and contribute to core resource loss

- All managers from the acquired entity who were opposed to the acquisiton deal must be removed in timely fashion.

These initiatives should help minimize potential conflicts and may lead to early conflict detection, along with determining the less cooperative employees in the acquired company. Also, offering proper financial packages to the retained employees should help minimize key talent loss during the integration stage.

I would like to emphasize that management should use the integration process as means, not as final goal. The integration effort should be reassessed using certain indicators for the purpose of reaching maximum value for the owners following the M\&A deal.

\section{Field Research: Post-merger Integration in the Republic of Macedonia}

The empirical research took place in 2014 and encompassed ten enterprises headquartered in the Republic o Macedonia that are or were subject to merger and/or acquisiton. The reserach helps understand the integration particularities of Macedonian enterpises that took place in an M\&A deal while examining the organizational difficulties which leads to better understanding and removal of these obstacles in the future.

The research was conducted in the form of questionnaire where employees from the selected enterpises expressed their opinion on multiple organizational aspects: organizational structure during integration, management systems integration, human resource integration 


\section{MIN Macrothink}

International Journal of Accounting and Financial Reporting

ISSN 2162-3082

2016, Vol. 6, No. 2

management, employee compensation system integration, integration process effectiveness.

The reserach framework encompassed staff that were working for local companies subject to merger/acquisiton. The sample included employees on managerial and non-managerial positions, with particular emphasis on individuals who were part of the acquisition topic or represented the companies in front of different audiences when publishing data of this character. The companies subject to this field research were mainly from the banking industry (four companies), communications industry (three entities), energy industry (one entity), construction industry (one entity), and transport and logistics industry (one entity).

Limitations to research results: the survey did not encompass employees who were no longer employed in the observed entities, i.e. had left the company in the aftermath of the merger event.

\subsection{Hypothesis}

Post-merger integration is key to the deal success. The motive behind evey merger/acquisition is synergy creation and increase of value by combining the participating entities. The synergy realization depends on the degree of structured human resource integration and the building of high-quality communication and team work across all levels, as well as the efficint human resource integration and promotion.

The post-merger organization synergy can be assessed through several indicators:

- Solid post-merger financials results

- Employee satisfaction

- Flexibility of the organization structure

- Policies focused on communication

- Efficient implementation of operating and structural reforms.

Communication, team work and human resource integration effectiveness can be assessed through:

- The engagement od staff across all departments in the organization integration process

- The preparation of communication and work process rulebooks

- Practical application of team work ethics to better organize work duties

We accept or overrule the hypothesis through core driver measurements which helps us realize if these drivers influence the expected synergy realization in integration.

\subsection{Analysis of the field research results}

After gathering the questionnaires, I have assessed the answers to several general parameters that categorize the success of the M\&A act and the integration process itself. 


\section{Macrothink \\ International Journal of Accounting and Financial Reporting \\ ISSN 2162-3082 2016, Vol. 6, No. 2}

- Integration success

The participants have expressed their opinion on the financial results before and after the integration.

Graph 2. Survey participants assessment of financial results before and after integration

\section{Financial results of the company}

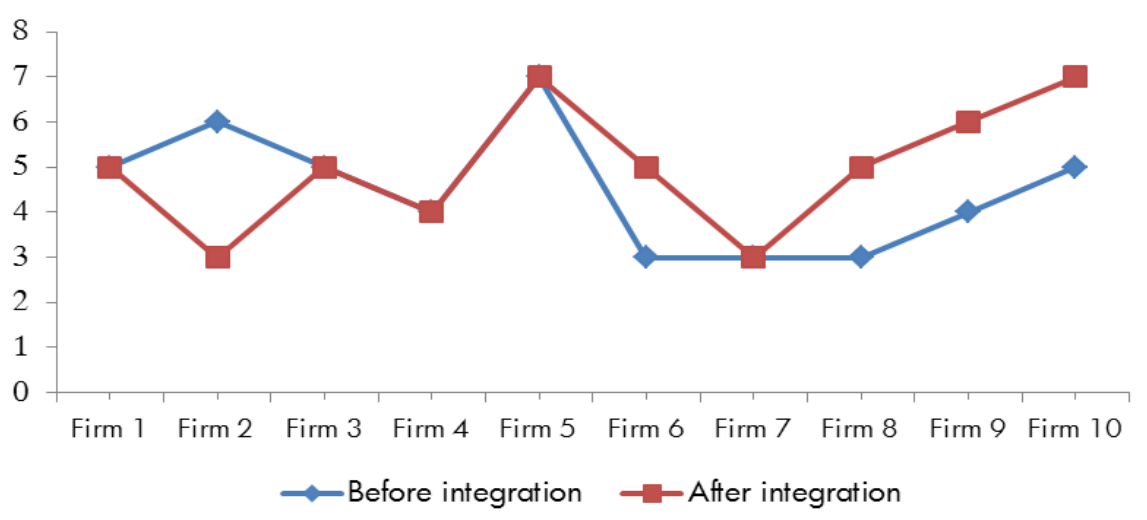

The participants with managerial status rank the post-merger financial results a bit more favorable, but nonetheless there is a general post-merger improvement in the company financials. Namely, almost all participants rate the post-merger financials close to or above the average result, unlike the pre-merger period.

Cca.50\% stated that the integration process lasted from six months to one year, whereas $40 \%$ said that the process lasted longer than one year. 


\section{Macrothink \\ International Journal of Accounting and Financial Reporting \\ ISSN 2162-3082 2016, Vol. 6, No. 2}

Graph 3. Duration of the integration process

\section{Integration duration}

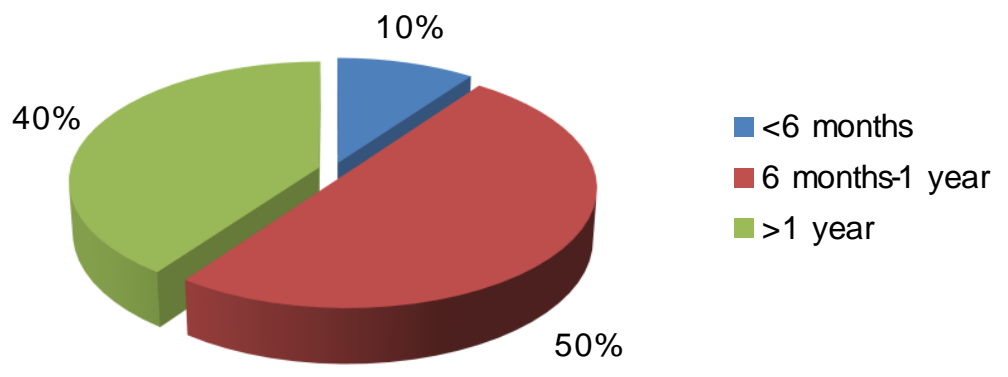

When it came to evaluating the engagement of staff across all organizational untis, most participants provided positive answers. The sole difference was between engagement of managerial and non-managerial employees. It is rather evident that all managers took place in the integration process without exceptions, while non-managerial staff were engaged based on need.

Table 2. Integration involvement

\begin{tabular}{lll}
\hline Integration process engagement & & \\
\hline & Yes & No \\
Managerial staff & 30 & 0 \\
Non-managerial staff & 37 & 7 \\
\hline \hline Total & 67 & 7 \\
\hline
\end{tabular}

As far as active participation is concerned, the survey participants pointed out that special teams were created to promote the integration between the two entities. Team creation practice was present in approximately $90 \%$ of the companies. 


\section{Macrothink

Graph 4. Integration teams

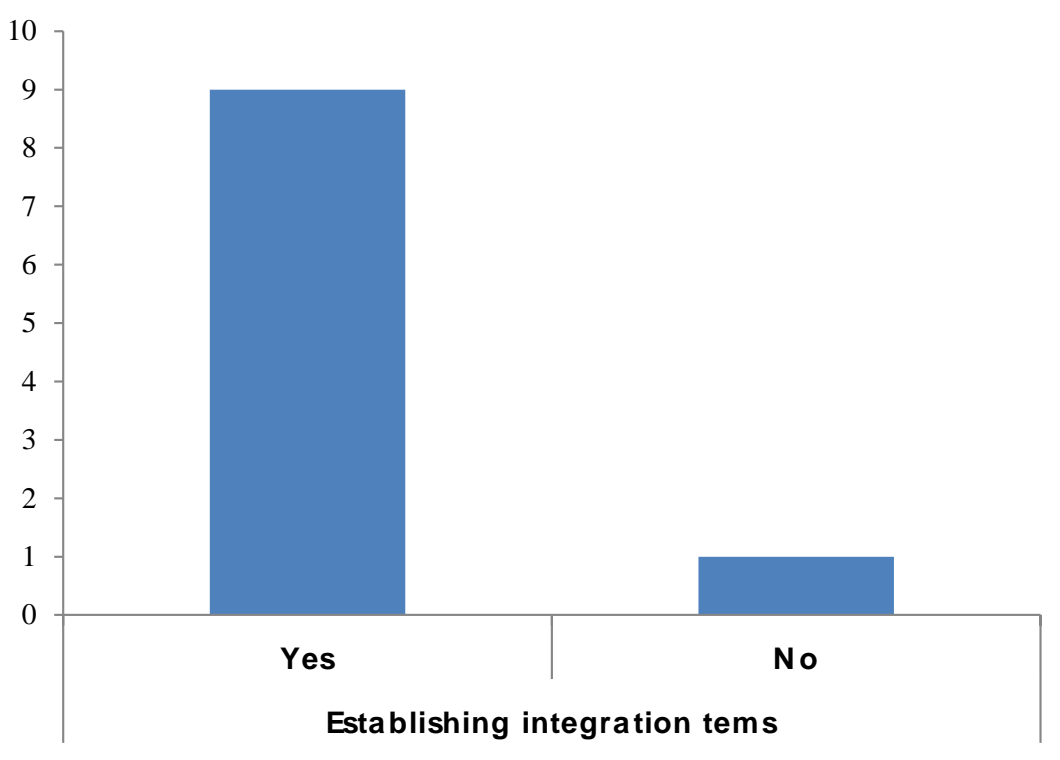

Integration teams were established in all the companies where almost all employees took an active part in integration. Hence, the correlation between these two activities is straightforward.

Most of the non-managerial employees claim that the leaders were vague when it came to stating the post-integration expectations. Therefore, the process demanded better clarity, transparency of the porocess roll-out and the period following integration completion. On the other hand, managers were more familiar with the post-integration expectations, which can be depicted as follows:

Table 3. Clarity of the mission and vision of the new company

\begin{tabular}{lcc}
\hline Clarity of new missions and vision & & \\
\hline & Yes & No \\
Managerial staff & 30 & 0 \\
Non-managerial staff & 30 & 14 \\
\hline \hline Total & 60 & 14 \\
\hline
\end{tabular}

Finally, most of the respondents stated that there was no assessment of the first 100 postmerger days as pictured in Graph 5. 


\section{Macrothink

Graph 5. Evaluation of the first 100 integration days

\section{Assessment of the first 100 days}

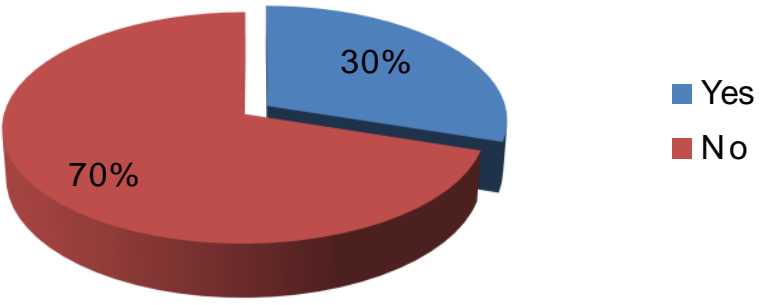

Namely, approximately two thirds of the respondents expressed negative opinion in terms of early integration evaluation.

\section{- Team work and communication}

Almost all reserch participants stated that communication and team work improved after the integration. Prior to integrating, the average presented on 1 to 7 scale (1 being the lowest score, and 7 the highest) was at 3.3 or: 4.3 in the financial industry, 3.0 for communiatons segment, 2.3 for the three remaining industries that were part of my field research.

Graph 6. Communication levels before integration

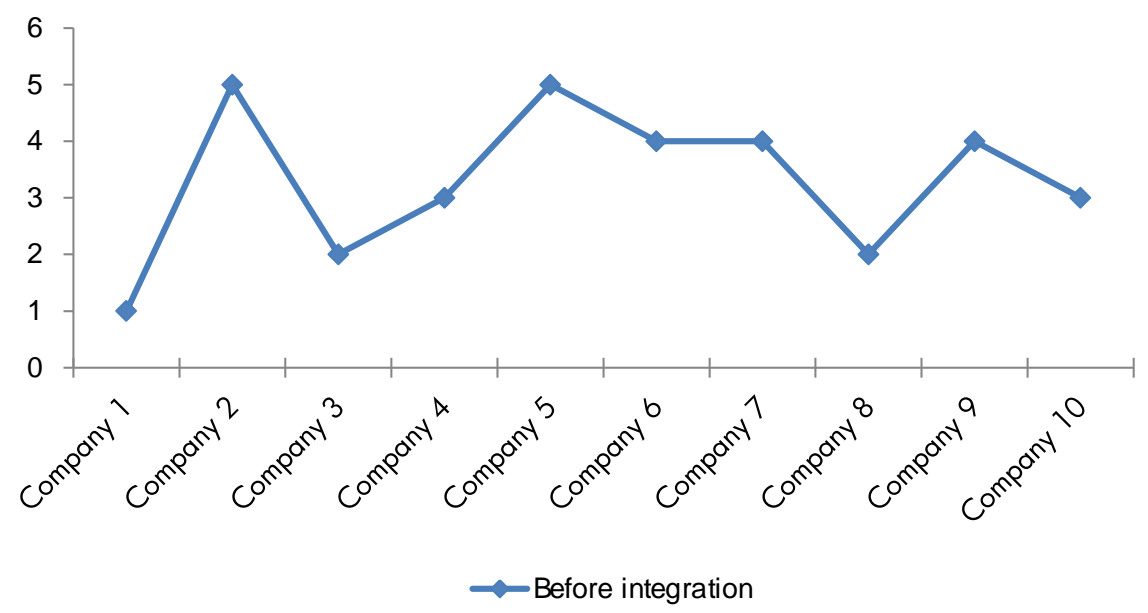

The respondents stated that the successful integration had a considerable impact on their departmental and inter-departmental relations, along with eliminating the operations obstacles. 


\section{Macrothink \\ International Journal of Accounting and Financial Reporting \\ ISSN 2162-3082 2016, Vol. 6, No. 2}

Management were slightly less postive than non-managerial staff when it came to assessing improvements in communication.

Graph 7. Elimination of communication hurdles

\section{Quality of communication after integration}

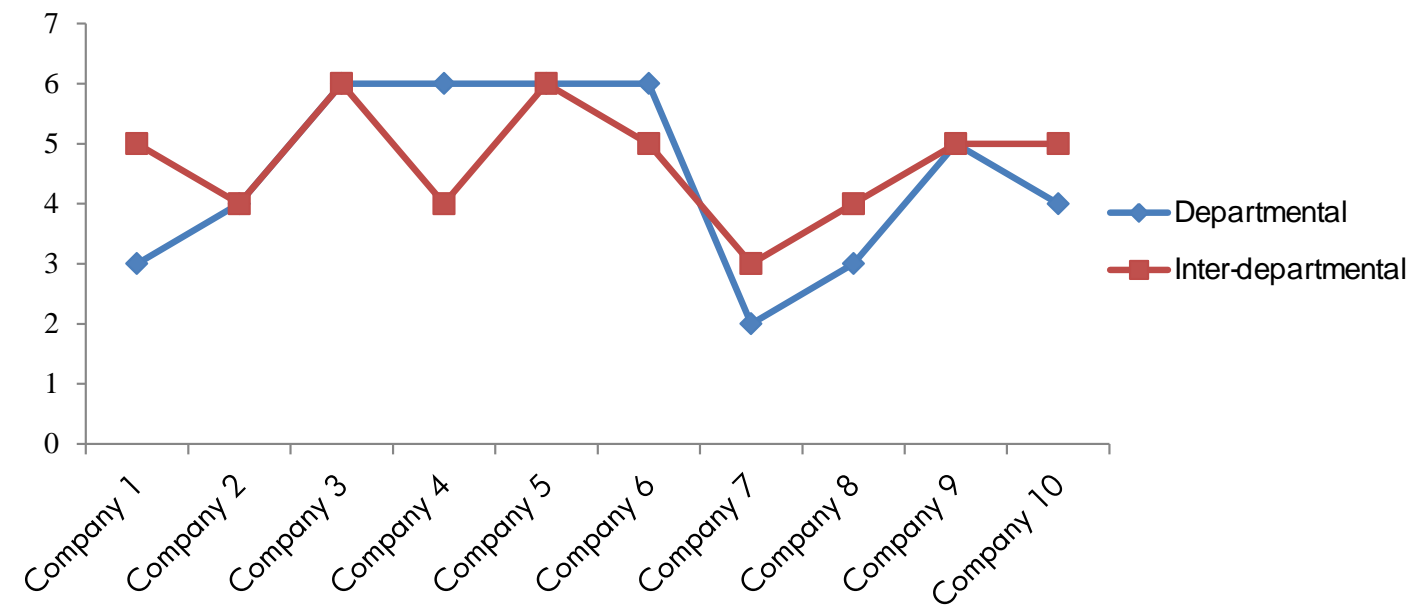

The sole exception comes from the energy segment where managers stated that communication following integration visibly deteriorated. On the other hand, the greatest difference in opinions between managerial and non-managerial staff came from the transportation industry respondents. The average score for departmental communication rating is 4.5 points, where 7 stands for maximum succes. The highest average is depicted in finance industry (4.8 points). The communications industry respondents point to worse work environment with an average of 3.8 points, which is nonetheless an improvement to the preintegration period (average 3.0 points before merger).

Regarding the communication across departments, the weighted average in amount of 4.7 points slightly surpasses the level of relations within individual departments. Across industries, the differences are immaterial as the same opinion prevails, with slightly higher grading in the banking sector (i.e. 4.8 points). Managers claim that the integration had a meaningful impact on cooperation across departments (50\%), $25 \%$ think that the impact was considerable, while the remaining $25 \%$ stated that the integration has minor or no influence on the communication between organizational units. The employees have more neutral opinion, with weighted average of 4.0 points.

The reserach participants stated that the integration process had significant influence on the legal organization and the preparation of written procedures for organizing and simplifying the work flow and work processes. 
Graph 8. Preparation of rulebooks and written procedures to promote work flows

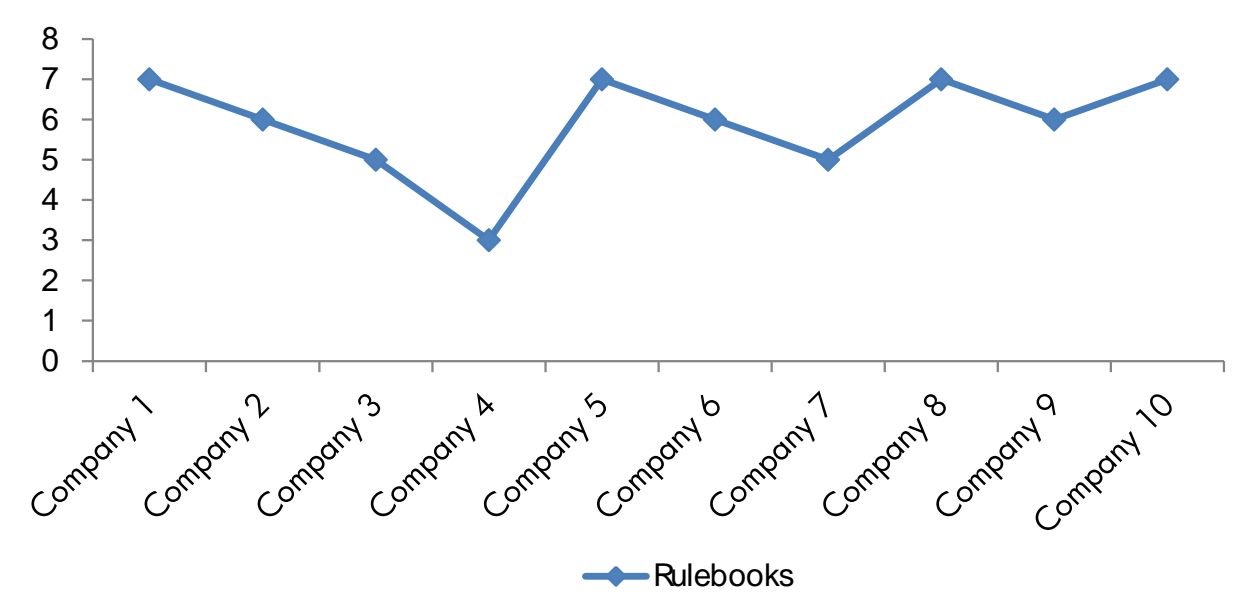

The score depicts high average grading of 5.9 points, where telecommunications industry was rated at 6.7 points, the finance industry had 6.0 points, while the other industries marked weighted average score of 5.0 on 1 - 7 scale.

Furthermore, in $40 \%$ of the M\&A cases, there was a moderate degree of integration of the acquired entity with the acquiring company, i.e. there was no complete absorption of the organization across all operating segments.

\section{Graph 9. M\&A Integration Intensity}

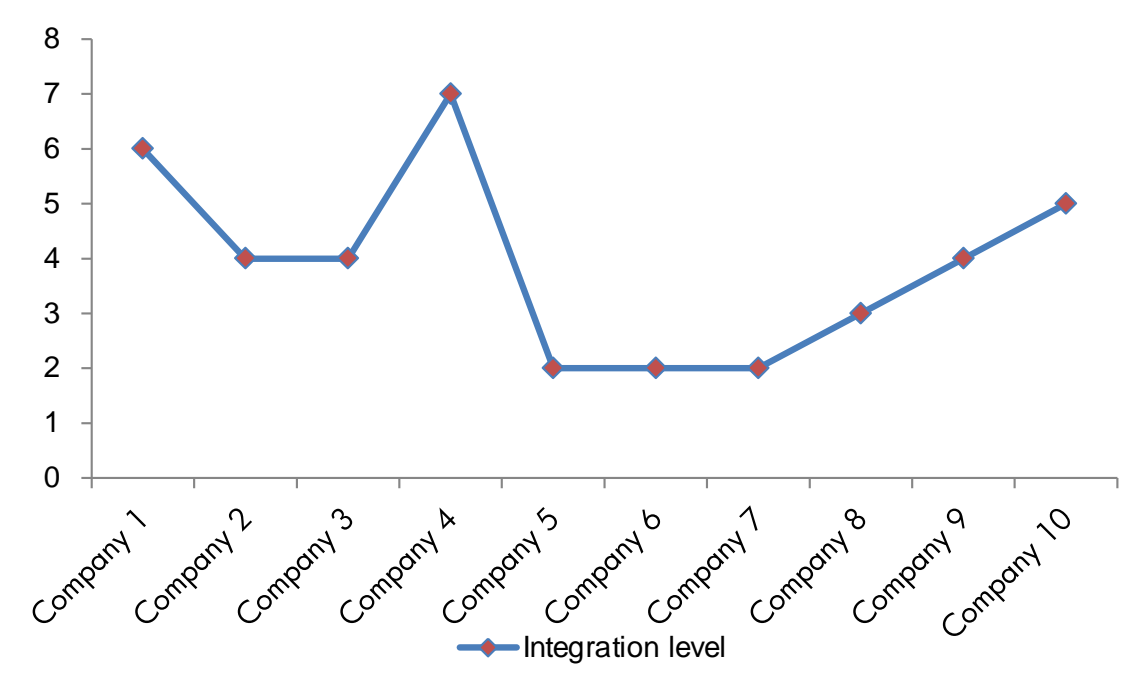

Answers to this category were similar for management and non-managerial staff. The answers pointed to a complete absorption (banking industry), whereas the other sectors stated that the pre-merger decision-making processes were preserved in the post-merger stage. The weighted average score is 3.9 points, which depicts a partial integration or absoption only in certain operating segments, such as finance sector and marketing activities. Banks go for 


\section{Macrothink}

International Journal of Accounting and Financial Reporting

ISSN 2162-3082 2016, Vol. 6, No. 2

highest integration levels, with weighted average of 2.5 points (the score of 1 representing complete absorption).

There is high correlation between the previous question and the topic of leadership style practiced following the M\&A act.

\section{Graph 10. Leadership style before and after merger}

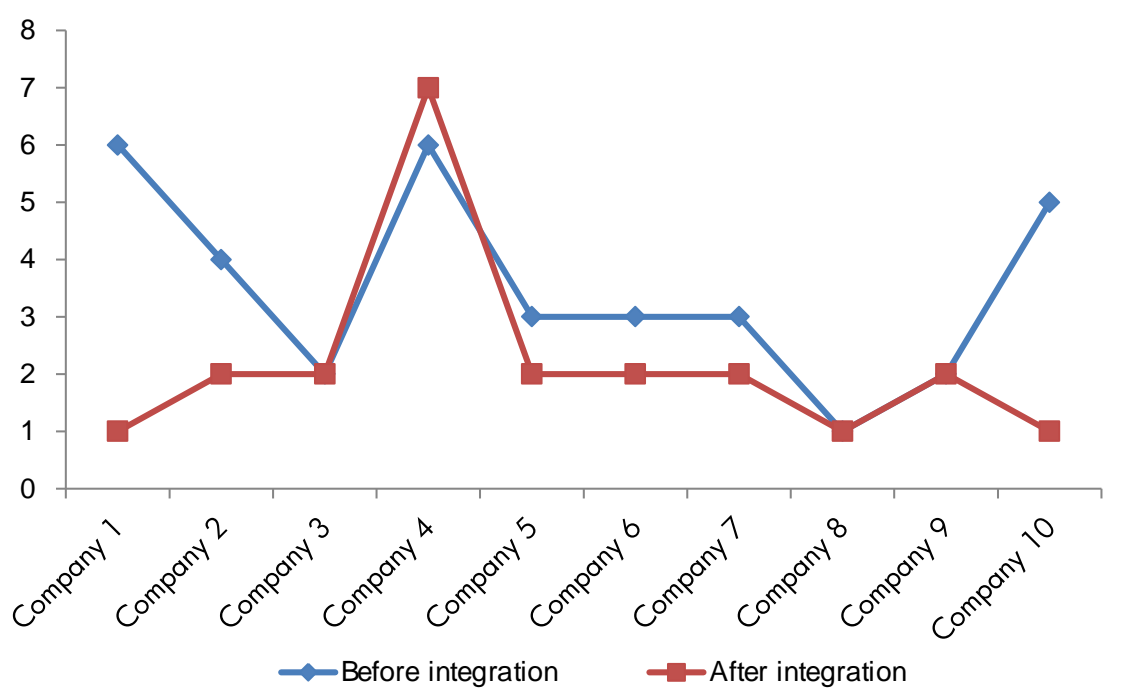

Namely, while the a priori score settles at 3.5 points and reveals a decentralized work flow organization style, the score turns into 2.2 points a posteriori in favor of centralized organization structure. The centralization towards the acquiring company is highest in telecommunications industry, with weighted average of 1.3 , followed by the banking industry and its 2.0 score. The results are understandable given the necessity to integrate IT and finance systems in the above-mentioned segments, especially billing systems and customer service systems in the communications industry.

According to the survey participants, the integration enhanced team work as opposed to individualism. 


\section{Macrothink

Graph 11. Team work before and after merger

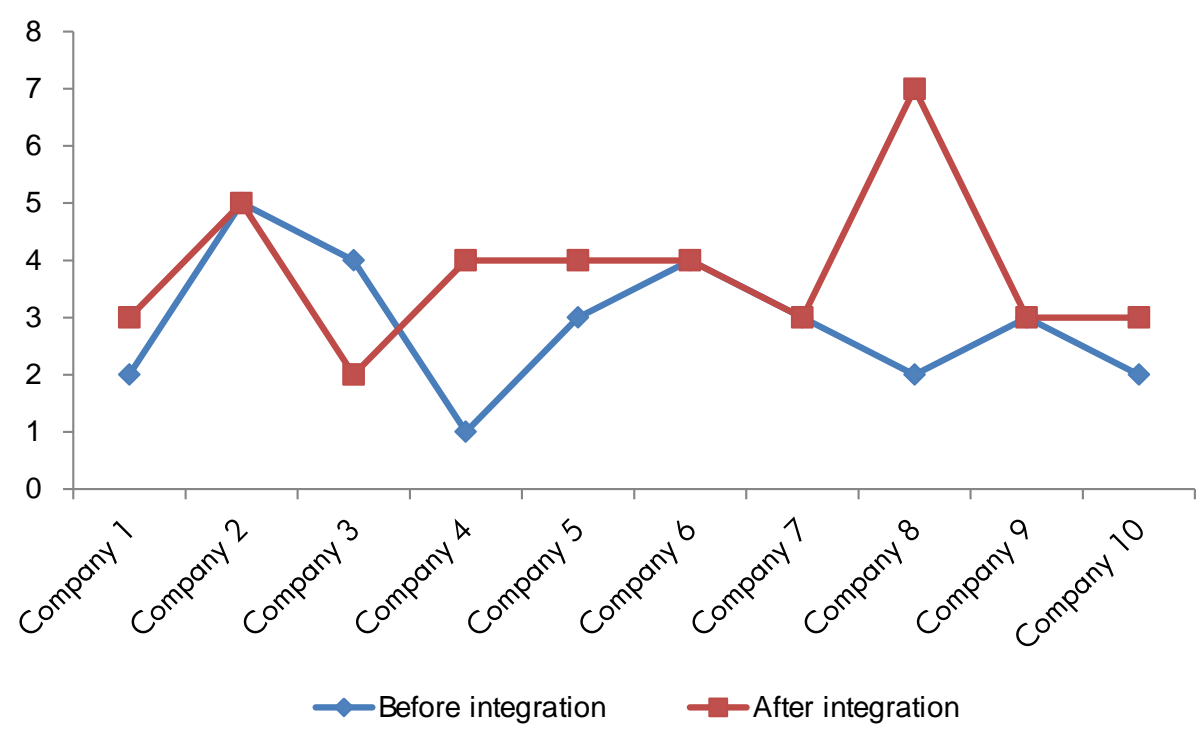

$60 \%$ of our respondents on managerial position pointed to team work improvement, while non-management had a score of $70 \%$. When it comes to the weighted average, the respondents stated that conservative approach (hierarhical) was predominant prior to merger (score of 2.9 points) as opposed to the post-merger period when the team work score reached 3.8 points. The finance industry had least changes in this regard (from 3.3 points a priori to 3.5 points a posteriori). Communications sector depict a change from 3.0 to 3.7 points, while the remaining industries show high team work focus after merger ( 2.3 before vs 4.3 after).

Furthermore, the respondents stated that the integration also improved the functioning of the work teams.

Graph 12. Team efficiency after merger

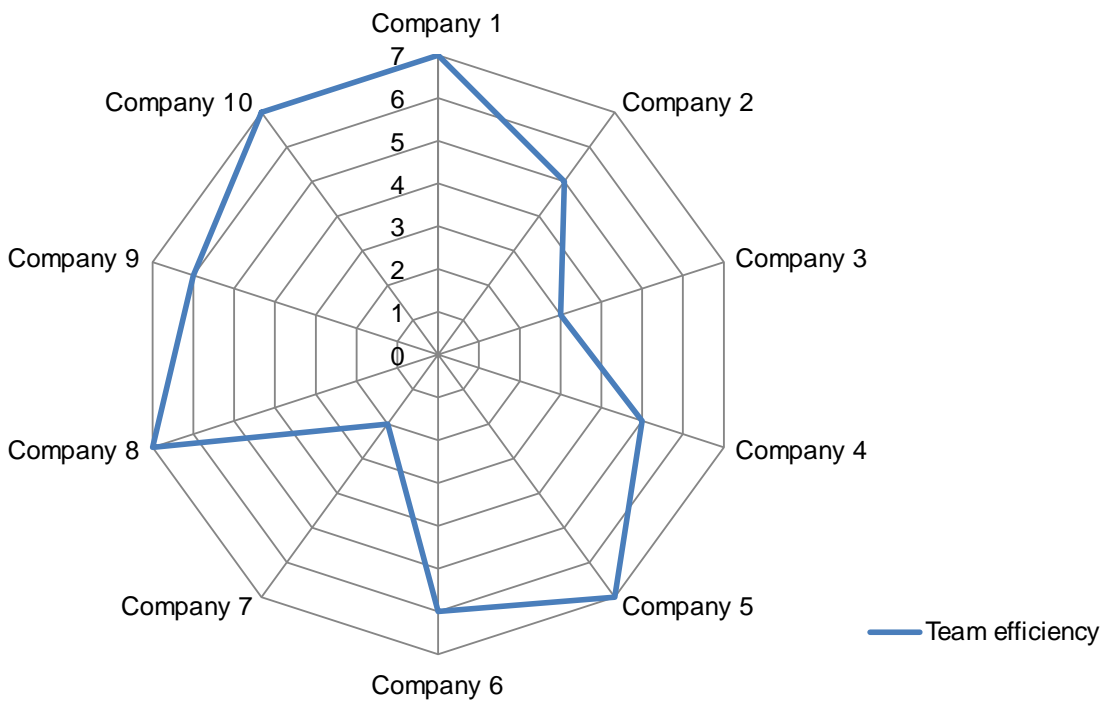




\section{Macrothink}

International Journal of Accounting and Financial Reporting ISSN 2162-3082 2016, Vol. 6, No. 2

Managerial and non-managerial staff displayed different attitudes, as $75 \%$ of managers said that the responsibility of team members has improved, while $25 \%$ opted for moderate improvement. Employees state that the responsibility of team members improved $(70 \%$ of the respondents), while the others claim that the M\&A act did not affect considerably the team work efficiency. The weighted average is 5.5 points, with communications industry average of 6.3, bank sector score of 5.3, and other industries score of 5.0 points.

\section{- Human Resource integration}

Numerous respondents stated that after the M\&A transaction moderate changes were implemented in the employee compensation system.

Graph 13. Changes to the employee compensation system in the post-merger period

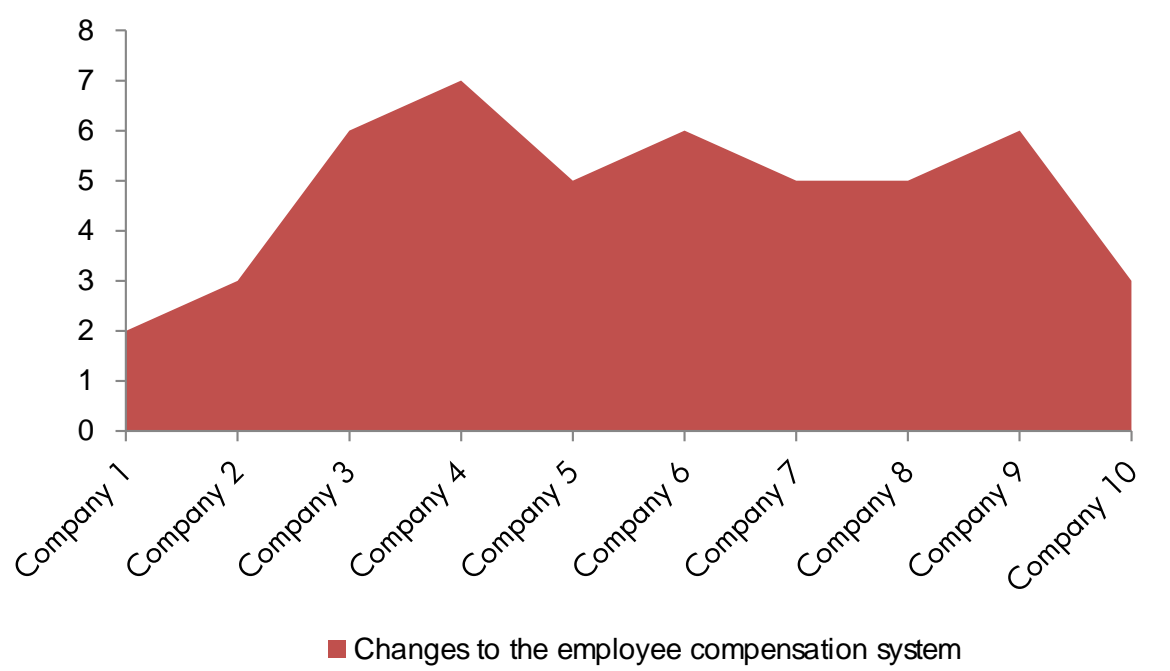

In this regard, given the 1 to 7 attitude scale, the weighted average of 4.8 depicts moderate adaptations, with 5.5 points in the finance industry, 2.7 in telecommunications, and 6.0 in the other three industries subject to this field study. Overall, M\&A events trigger greater intercompany alignments of employee compensation systems.

According to the research participants, the integration inspired greater emphasis on the importance and the reward of collective interest. 


\section{Aacrothink \\ International Journal of Accounting and Financial Reporting \\ ISSN 2162-3082 2016, Vol. 6, No. 2}

Graph 14. Employee compensation system: Importance of collective interests in the pre-and post-merger period

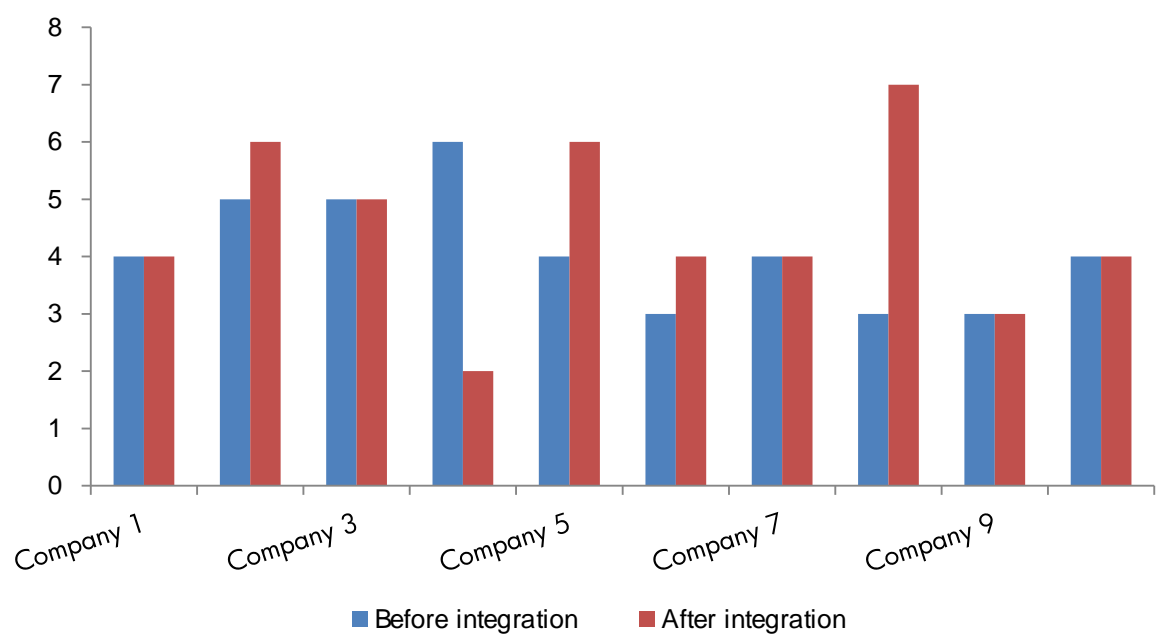

$50 \%$ of the companies stated that employee compensation portrayed no particular emphasis on saveguarding the colletive interests following the merger. Nonetheless, the post-merger score of 4.5 points displays focus on collective rather than individual interests, unlike the 4.1 score for the pre-integration period. The greatest alignment in favor of collective interests inclusion in employee compensation was visible in the banking sector (4.7 points), which leaves less space for recognition of individual interests and achievements.

When asked about management changes and department restructuring, $80 \%$ of the survey participants opted for a confirmative answer.

\section{Graph 15. Management team restructuring}

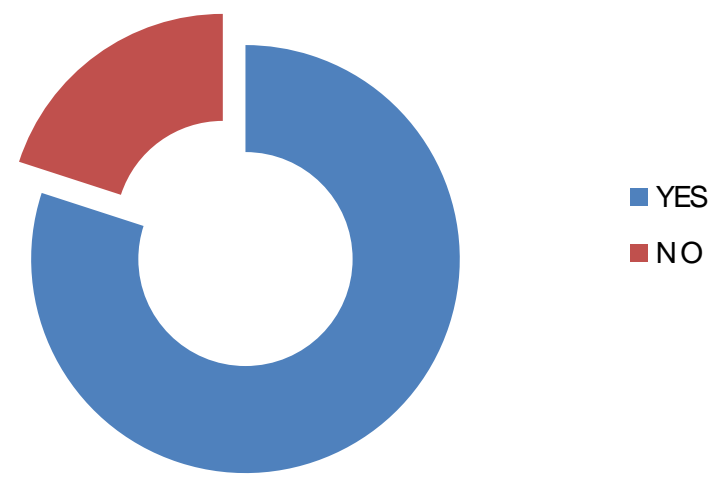

Namely, the weighted average score was 3.2, with largest changes in the communications industry, energy sector and transport industry. This score fits the centralized approach, i.e. absorption of the target by the acquiring company, or partial absorption of certain operating segments, in particular the financial and managerial structures.

However, the respondents stated that the integration had deteriorating impact on employee 


\section{Macrothink

loyalty towards the company.

Graph 16. Employee loyalty before and after merger

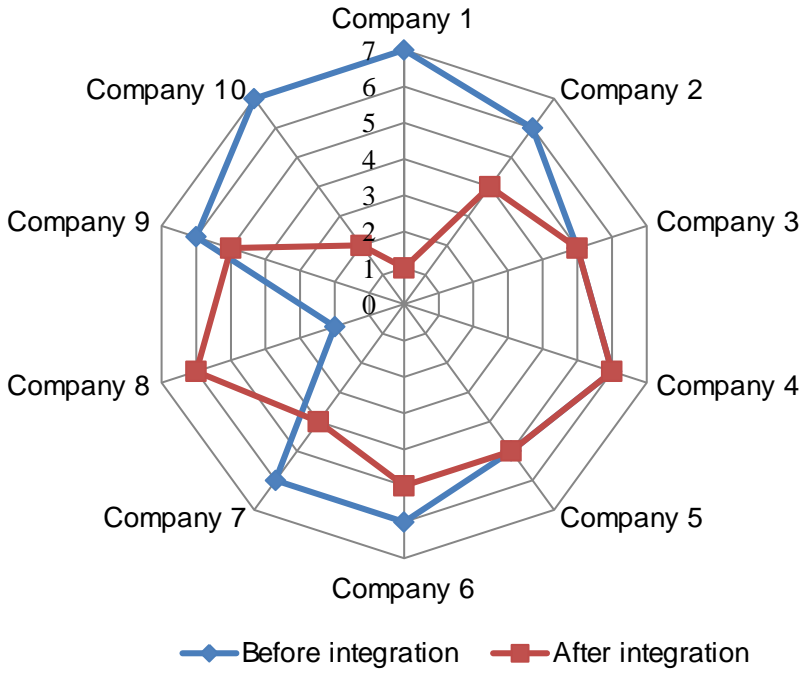

Managerial and non-managerial staff expressed different opinions, with $75 \%$ of managers stating that loyalty level dropped. $50 \%$ of non-managerial staff claimed that loyalty improved, while the other half said that the merger did not have impact on loyalty levels. The weighted average before integration was 5.6, and changed to 4.3 after integrating. Telecommunications sector is ahead of all other surveyed industries in terms of loyatly drop with 2.3 points, with banks following with 4.8 points, and the others opting for an average of 5.7 points. The telecommunications score dropped from 6.7 to 2.3 points, whereas banks dropped from 5.8 to 4.7 points. The transport and energy sectors did not depict noticeable changes in loyatly level.

In addition, the respondents stated that the integration deteriorated the loyalty of the enterpise towards the employees.

Graph 17. Employer loyalty before and after merger

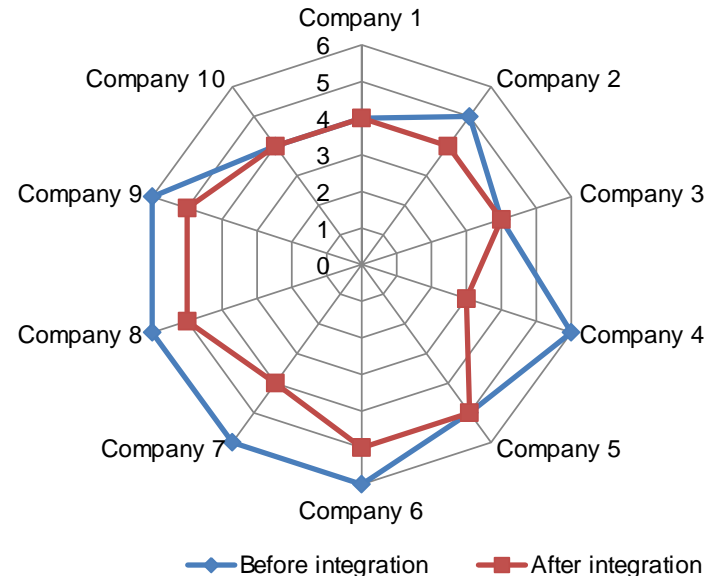




\section{Macrothink}

International Journal of Accounting and Financial Reporting

ISSN 2162-3082

The average a priori score was 5.2 points and changed to 4.3 points a posteriori. The construction industry and the telecommunications display the largest employer loyalty drop with a 4.0 score, followed by banking sector with 4.3 points after integration. Loyalty is reciprocal, which explains the attitude expressed by the research respondents. Conclusively, both the employee and employer loyalty worsened in response to major company restructuring following any merger or acquisition event.

According to the opinion the the survey participants, the integration led to larger dissatisfaction amongst amployees due to change in employee treatment after merger.

Graph 18. Employee satisfaction before and after integrating

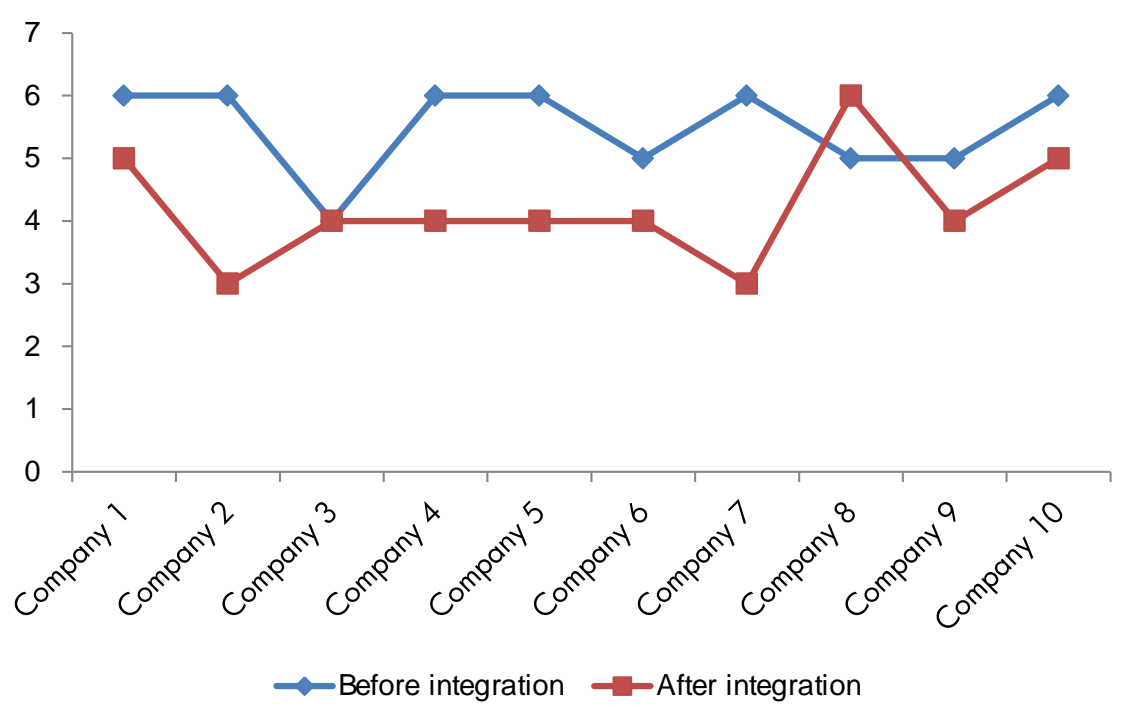

Graph 18 shows that there is an apparent decline in employee satisfaction due to changed employer treatment after merger. The average score plunges froms 5.5 to 4.2 points, with highest drop in telecommunications (from 6.0 to 4.3 points) and banks (from 5.5 to 3.8 points).

Finally, our respondents stated that the integration eliminated or reduced the existing informal management information systems. 
Graph 19. Informal management information systems before and after integrating

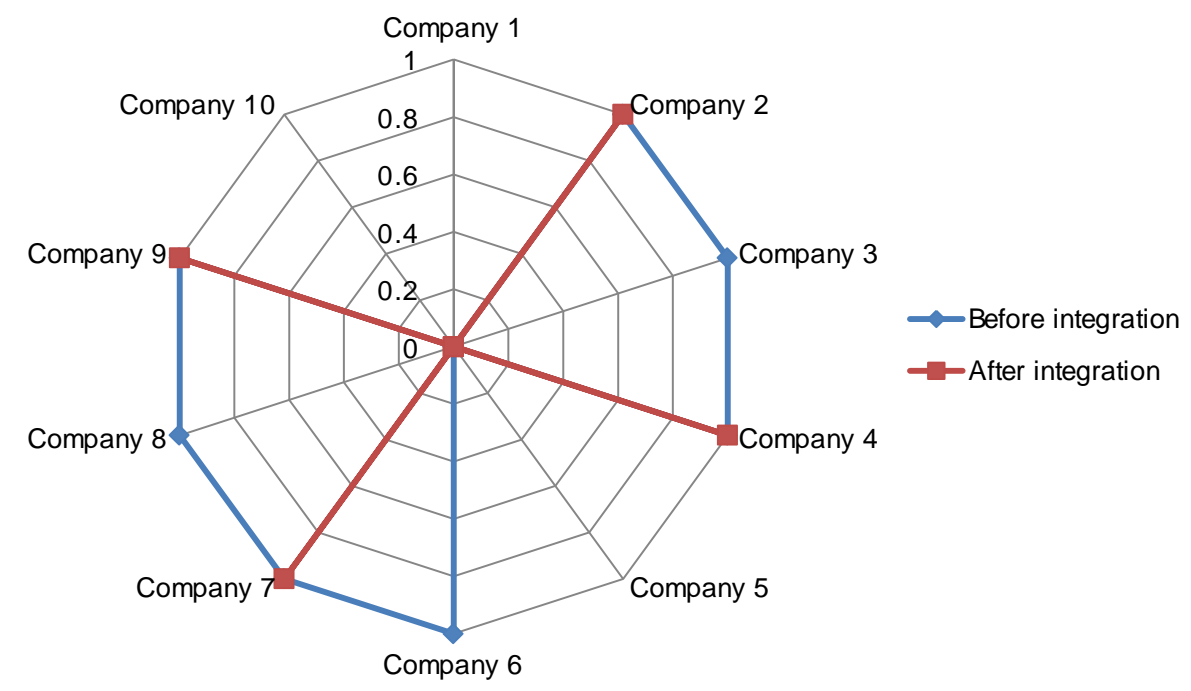

This topic is tightly interrelated with the existence of procedures and rulebooks in the context of regulating the new entity's operations. The repondents stated that integration allowed for establishment of formal procedures. Certainly, the reduction of informal management systems is useful for employees and reduces uncertainties as to personal expectations and achievements. Ergo, in $70 \%$ of the cases informal management systems existed before merger, with this ratio dropping to $40 \%$ following the completion of the integration process. The largest improvements were present in the energy and transport sector, while telecommunications and construction industry showed no visible changes in this regard. Namely, the construction sector is still run by informal procedures and guidelines.

Finally, the respondents were asked if they thought that the reforms of the previously existing information systems were successful. $70 \%$ answered that the efiiciency is noticeable, while the remaining $30 \%$ were not satisfied with the reform speed. The negative answers were mainly from the construction, energy and transport industry respondents, whereas banking and communications sectors displayed speed and efficiency in reforming the previous informal systems.

\section{Conclusion.}

Organizational synergy drives all merger and acquisition transactions in the business community. However, the essential spice comes from adequate organizational transformation within the newly established entity, and if the transformation is efficient and effective, the communication will improve, along with team work and human resource integration as essential building blocks of every entity. 


\section{Macrothink \\ International Journal of Accounting and Financial Reporting \\ ISSN 2162-3082 2016, Vol. 6, No. 2}

Graph 20. Integration process: inputs and outputs

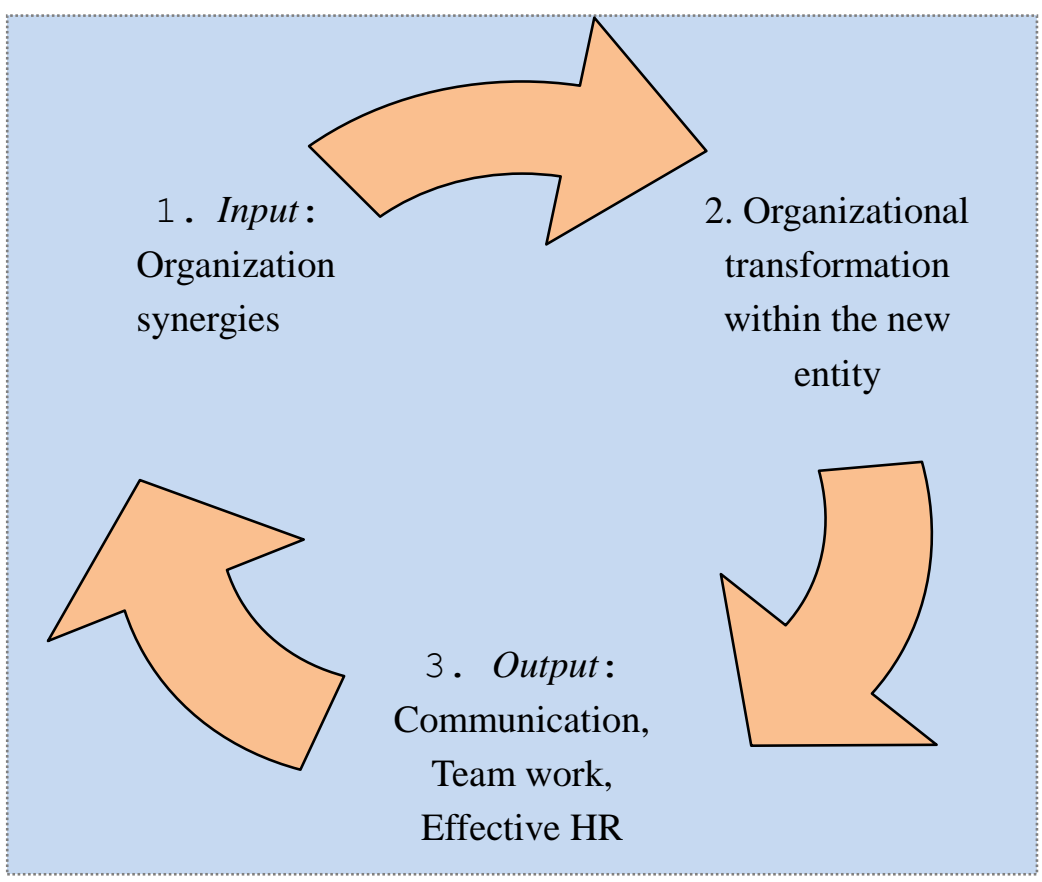

The field research demonstarted that if the M\&A act helped realize the desired organizational synergy, then there is high rating of communication and team work, which confirms the field research Hypothesis. Namely, if the entity's bottom line finances improved, if employees were actively involved in the integration process, and if special integration teams supported the process, there is a high degree of communication and team cooperation.

The ameliorated departmental and cross-departmental cooperation, along with written procedures on work duties are evident in enterprises with successful financial operations as a result of M\&A transformation. Solid communication and decentralization are practiced in enterprises where employees are more content with the new circumstances, which is followed by common acceptance of team work and team efficiency, where every team member is fully responsible for quality fulifillment of their own work duties.

Furthermore, the empirical part of my research demonstarted that if the M\&A synergy comes to life, then human resources integrate effectively as a result of employee satisfaction and operational contribution. In fact, team work is promoted across all domains where synergies were realized following the establishment of new procedures and individual duties regulation.

Another crucial norm is fulfilling the promises given. By attaining the desired goals, management established credibility in front of the Management Board and the investors, which improves the ability to attract fresh external capital that supports the introduction of new products or merger/acquisition plans. The acquiring companies are ready to invest more in organizations that keep their promises. Sound internal norms vouch for continous progress of the company.

Real life experiences demonstrate that more than half of merger and acquisition transactions do not fulifill the promises given, or they procrastinate with promise fulfillment. 


\section{Macrothink}

International Journal of Accounting and Financial Reporting

ISSN 2162-3082

2016, Vol. 6, No. 2

Approximately one third of transactions are labeled as successful by management. Nonetheless, all historical failures are driven by unfinished home work or diversification in an unrelated industrial segment. Nowadays failures are often driven by poor post-merger integration. Certainly, unsuccessful mergers demoralize the acquiring company and induce profit erosion, which eventually transforms the 'hunter' into a target.

In order to avoid unnecessary distress, I strongly recommend to create new formal work positions before embarking on such complex transactions, and to create integration teams. This will place larger emphasis on core integration domains, such as human resources, operating systems, employee compensation system, information technology and sales channel integration. Common vision, short-term employee benefits, company cultures, geography similarities, and long-term benefits for all parties involved are core success factors.

Moreover, information flow is of vital meaning for every integration phase. The goal, tasks, responsibilities, and main documents related to the current integration phase need to be adequately provided to participants across all organizational units in order to evaluate the organization capacity and to improve communication across all units. Also, tracking systems must exist in order to detect integration problems and limitations at an early stage and address them.

Finally, in my personal experience, the most vital determinants of every integration success are:

- Critical timeframe: one year

- The process must be smooth,objective, and effective

- Strategy must be subject to continuous improvement

- Integration and strategy must be aligned

- Integration managers should be part of the team running negotiations

- The deal should not come to life unless a leader is appointed

- Top managers and top performers should be adequately stimulated

- There must be a constant moderate pressure to achieve solid results

- Fast decision-making

- Going back to normal operating mode as soon as possible

Financial analysts have always had greater intuition for resource worth rather than for process worth although both items go hand in hand. In fact, all resources, processes and values are essential for the merging entities.

\section{Acknowledgement}

The research is supported by UACS Skopje: http://www.uacs.edu.mk/home/ 


\section{Macrothink}

International Journal of Accounting and Financial Reporting

ISSN 2162-3082

2016, Vol. 6, No. 2

\section{References}

Alex Tajirian, 1997: “Acquisitions. Chapter 19”, http://morevalue.com/ireader/ftp/Ch19.PDF, 30 May 2006.

AllExperts, "Kohlberg Kravis Roberts \& Co.”, http://experts.about.com/e/k/ko/Kohlberg_ Kravis Roberts_\&_Co.htm, June 2008.

Angelova, Biljana. "Budgeting system of accounting planning of costs and company financial results”, Ekonomski institut, Skopje, 2001.

Astrachan, J. H. 1990. Mergers, Acquisitions, and Employee Anxiety: A Study of Separation Anxiety in a Corporate Context. New York, NY: Praeger.

Booz Allen and Hamilton, Merger Integration: Delivering on the Promise, http://www.boozallen.com/media/file/76776.pdf, 1 November 2007.

CMS Cameron McKenna, M\&A Integration. A Merger market Report on Issues Surrounding Post-deal Integration for European Companies, http://www935.ibm.com/services/uk/bcs/pdf/ma_integration260107.pdf, April 2016.

Daniel, Teresa A and Metcalf, Gary S. The management of people in mergers and acquisitions. Westport, Conn: Quorum Books; 2001.

David Schweiger, , M\&A Integration : A Framework for Executives and Managers, McGrawHill Companies Inc. 2002, New York.

Deal, Terrence E. and Kennedy, Alan A. The new corporate cultures: revitalizing the workplace after downsizing, mergers, and reengineering. Reading, Mass: Persus Books; 1999.

Deloitte Consulting LLP, Merger \& Acquisition Library - Integration, http://www.deloitte.com/dtt/article/0,1002,sid=109077\&cid=161540,00.html, 11 September 2007

Deloitte Consulting LLP, Managing M\&A Facilities Integration, http://deloitte.com/dtt/cda/doc/content/US_MA_Managing\%20MA\%20Facilities\%282\%29.p df, 7 July 2007.

Deloitte Consulting LLP, Merger Aftershocks. Surviving the people challenges of a postmerger integration, http://www.deloitte.com/dtt/cda/doc/content/us_consulting_hc_MergerAftershock_190907.pd f, 7 July 2007.

Deloitte Consulting LLP, From Signing to Close, http://www.deloitte.com/dtt/cda/doc/content/us_ma_From\%20Signing\%20to\%20Close.pdf, 10 October 2007.

Deloitte Consulting LLP, Sharks, Sales Force, and Merger Integration, http://www.deloitte.com/dtt/cda/doc/content/us_ma_Sharks\%20Sales\%20Force\%20and\%20 
Merger\%20Integration\%20FINAL.pdf, 19 October 2007.

Deloitte Consulting LLP, Sharks, The Secrets of Successful Mergers, http://www.deloitte.com/dtt/cda/doc/content/ca_DR_SuccessMergers_Feb2004\%281\%29.pdf , 23 March 2007.

Deloitte Development LLC, Navigating a Global Merger, http://www.deloitte.com/dtt/cda/doc/content/us_ma_Navigating\%20Global\%20Merger.pdf, 24 March 2007.

Deloitte Development LLC, Making Price Management a Priority Can make the Difference between Success and Failure in M\&A, http://www.deloitte.com/dtt/cda/doc/content/us_consulting_so_pricingma_250906.pdf, 24 March 2007.

Deloitte Development LLC, Beating the Merger Integration Odds, http://www.deloitte.com/dtt/cda/doc/content/us_consulting_mergerintegration_ss_171006.pdf , 25 March 2007.

Deloitte Development LLC, The Journal of Professional Pricing, First Quarter 2007, Using Prices to Unlock More Merger Value, http://www.deloitte.com/dtt/cda/doc/content/us_pricing_Using\%20Pricing\%20to\%20Unlock $\% 20$ More\%20Merger\%20Value.pdf, 2 August 2007.

Economic Advisory Group for Competition Policy (EAGCP), "Non-Horizontal Merger Guidelines: Ten Principles. A Note by the EAGCP Merger Sub-Group", http://72.14.209.104/search?q=cache:qQwOneUh7-IJ:ec.europa.eu/ comm/competition/mergers/legislation/non_horizontal_guidelines.pdf+EU+vertical+mergers +guidelines\&hl=en\&ct=clnk\&cd=1, 17 August 2006.

Eric M. Gauthier, Post-Merger and Acquisition Integration in an Enterprise Solutions Environment, http://www.accenture.com/Global/Research_and_Insights/ Outlook/By_Alphabet/PostMergerEnvironment.htm, August 2007.

Mangesh Sawant, A Strategy for M\&A Integration, 06/03/2002, Datamatics Technologies,http://www.ebizq.net/topics/erp_integration/features/1739.html, 5 August 2007

Nicolas J. Albizzatti, Scott A. Christofferson, and Diane L. Sias, The McKinsey Quarterly, "Smoothing Postmerger Integration", http://www.mckinseyquarterly.com, May 2016.

Feldman, Mark L and Spratt, Michael Frederick. "Five frogs on a log: a CEO's field guide to accelerating the transition in mergers, acquisitions, and gut wrenching change". 1st ed. New York: HarperBusiness; 1999.

Galpin, Timothy $\mathrm{J}$ and Herndon, Mark. "The complete guide to mergers and acquisitions: process tools to support M\&A integration at every level”. San Francisco: Jossey-Bass Publishers; 1999.

Garrison, R.H., Noreen E., "Managerial Accounting”, eight edition, 1997. 


\section{Ml Macrothink}

International Journal of Accounting and Financial Reporting ISSN 2162-3082 2016, Vol. 6, No. 2

Graeme K. Deans, Fritz Kroeger, and Stefan Zeisel, "Winning the Merger Endgame: A Playbook for Profiting from Industry Consolidation”, McGraw-Hill, 2002.

Grubb, Thomas M and Lamb, Robert. "Capitalize on merger chaos: six ways to profit from your competitors' consolidation and your own”. New York, N.Y: Free Press; 2000.

Hansen \& Mowen, “Cost Management Accounting and Control”, second edition, 1997.

Hawkins, David F., "Corporate Financial Reporting and Analysis", Irwin/McGraw-Hill: New York, 1998.

Hill, Charles W.L., “International Business”, Irwin/McGraw-Hill: Boston, 2000.

Hill, Kelly. "Cases in corporate acquisitions, buyouts, mergers, \& takeovers". Detroit, Mich: Gale; 1999.

Investor Words.com, http://www.investorwords.com/3045/merger.html, WebFinance, Inc, 10 October 2006.

IFR: International Financing Review, "An M\&A Dependency", http://www.ifre.com/ story.asp?sectioncode=714\&storycode=182766, 22 April 2006.

Makedonski Telekom, http://www.telekom.mk/mk/, 15 October 2008.

Marks, Mitchell Lee. Charging back up the hill: workplace recovery after mergers, acquisitions, and downsizing. San Francisco, CA: Jossey-Bass; 2003.

Patrick A. Gaughan, "Mergers, Acquisitions, and Corporate Restructurings", second edition, New York: John Wiley \& Sons, 1999.

Paul A.Pautler, "Evidence on Mergers and Acquisitions", Federal Trade Commission: Working paper, 25 September 2001.

Pearson, M." Mergers and Acquisitions in Financial Services: A Global Analysis of M\&A Corporate Strategy in the 1990s", Dublin: The Laferty Group, 1998.

Philippe Haspeslagh and David Jemison, "Managing Acquisitions", New Yowk: Free Press, 1991.

Philippe Haspeslagh and David Jemison, M\&A method - Acquisition Integration Approaches, http://www.valuebasedmanagement.net/methods_haspeslagh _acquisition_integration_approaches.html, Value Based Management, 13 November 2007.

Picot, Gerhard. Handbook of international mergers and acquisitions: planning, execution, and integration. New York: Palgrave; 2002.

Prof. Dr. Vasil Popovski, "Vlijanie na organizaciskata kultura vrz delovnosta na pretprijatijata”, Ekonomski Institut Skopje, Skopje, 2001.

Rezaee, Zabihollah. "Financial institutions, valuations, mergers, and acquisitions: the fair value approach". 2nd ed. New York: John Wiley; 2001. 


\section{Al Macrothink}

International Journal of Accounting and Financial Reporting

ISSN 2162-3082

2016, Vol. 6, No. 2

Samuel C.Thompson, Jr, "New M\&A Developments: Supplemental Cases and Other Materials for Business Planning for Mergers and Acquisitions. Reflecting Developments from January 2001 through January 20, 2006”, second edition, January 2001.

Schmidt, Jeffrey A; Towers, Perrin, Forster \& Crosby, and Society for Human Resource Management (U.S.). "Making mergers work: the strategic importance of people". 1st ed. Alexandria, VA: Society for Human Resource Management (SHRM); 2002.

Slowinski, Gene ; Rafii, Zia E. ; Tao, John C. ; Gollob, Lawrence ; Sagal, Matthew W.; Krishnamurthy, Krish, "After the acquisition: managing paranoid people in schizophrenic organizations; successful integration of the R\&D function requires management to focus on six factors", http://goliath.ecnext.com/coms2/summary_0199-1844990_ITM, 22 March 2007.

Stuart Ferguson, "Financial Analysis of M\&A Integration", McGraw-Hill Companies Inc. New York, 1 edition, 2003.

The Economist. Finance and Economics, "Mergers and Acquisitions. Partying like it's 1999", November-December 2006, Volume 381, No.8505.

The Perreault Birmingham Group LLC, Post M\&A Integration Planning and Implementation, http://thepbgrp.com/merger-acquisition-services/post.html, 1 November 2007.

Thompson, Samuel C. Business planning for mergers and acquisitions. 2nd ed. Durham, NC: Carolina Academic Press; 2000.

Weekly newspaper Kapital. "The world mergers and acquisitions in the first quarter with a net worth of 725 billion euros". Ekonomist doo Skopje, 20 April 2006, No.338.

Weekly newspaper Kapital. "Gorgi Janchecski, CEO of NLB Tutunska Banka. Next year we expect refreshment and stronger growth of the banking sector". Ekonomist doo Skopje, 9 November 2006, No.367.

Yaniv Grinstein and Paul Hribar, "CEO Compensation and Incentives - Evidence from M\&A Bonuses”, Johnson Graduate School of Management: Working paper, July 2003.

Zollo, Maurizio. "Post-acquisition Strategies, Integration Capability, and the Economic Performance of Corporate Acquisitions", Department of Strategy \& Management, Unpublished dissertation, University of Pennsylvania.

\section{Copyright Disclaimer}

Copyright for this article is retained by the author(s), with first publication rights granted to the journal.

This is an open-access article distributed under the terms and conditions of the Creative Commons Attribution license (http://creativecommons.org/licenses/by/3.0/). 